\title{
Hygienekampanjen høsten 2009 - færre infeksjonstilfeller på legevakt?
}

\author{
Sammendrag \\ Bakgrunn. I forbindelse med svine- \\ influensaepidemien høsten 2009 iverk- \\ satte myndighetene en kampanje for \\ bedre hygiene. Vi ønsket å undersøke \\ om kontaktraten for infeksjonssyk- \\ dommer på legevakt ble endret mens \\ denne kampanjen pågikk.
}

Materiale og metode. Data er hentet fra alle elektroniske refusjonskrav fra legevaktleger i årene 2006-09. Kontaktrater for ni infeksjonsdiagnoser høsten 2009 ble sammenliknet med et gjennomsnitt av de tre høsthalvårene 2006, 2007 og 2008.

Resultater. Kontaktraten for influensa var ti ganger høyere høsten 2009 enn de tre foregående årene. I samme periode var det signifikant færre tilfeller av konjunktivitt (kontaktrateratio $0,74)$, otitt $(0,73)$, sinusitt $(0,70)$, halsbetennelse $(0,79)$, pneumoni $(0,70)$ og tarminfeksjoner $(0,82)$. Det var små endringer i kontaktratene for akutt øvre luftveisinfeksjon og urinveisinfeksjon, men i desember måned var det også tydelig reduksjon for akutt øvre luftveisinfeksjon $(0,61)$.

Fortolkning. Den reduserte kontaktraten for infeksjonssykdommer er forenlig med en effekt av hygienekampanjen, men andre faktorer kan også ha bidratt til dette resultatet.

\section{Hogne Sandvik}

hogne.sandvik@isf.uib.no

Nasjonalt kompetansesenter for legevaktmedisin Postboks 7810

5020 Bergen

\section{Steinar Hunskår}

Nasjonalt kompetansesenter for legevaktmedisin og

Forskningsgruppe for allmennmedisin Institutt for samfunnsmedisinske fag Universitetet i Bergen

I månedsskiftet mars/april 2009 ble det oppdaget en ny type influensa A (H1N1) i NordAmerika. Infeksjonen spredte seg raskt over mesteparten av verden, og 11. juni 2009 erklærte Verdens helseorganisasjon den første influensapandemien siden 1968 (1). I Norge ble det iverksatt flere beredskapstiltak for å møte den nye epidemien. I tillegg til massevaksinering og medikamentell behandling av influensasyke ble det lagt stor vekt på smitteforebyggende tiltak. Helsedirektoratet og folkehelseinstituttet ga $\mathrm{i}$ juni ut en plakat med fire enkle hygieniske råd til befolkningen (fig 1). Rådene ble også gjentatt i TVkampanjer og var hyppig sitert i mediene.

Høsten 2009 var den norske offentligheten sterkt preget av svineinfluensaen. Myndighetene fryktet tidlig at epidemien kunne forårsake høy dødelighet, og norske medier forsterket denne frykten (2). Fastlegekontorene og legevaktene ble nedringt av engstelige pasienter (3). De hygieniske rådene gjorde imidlertid sin virkning. Folk vasket hendene, hostet $\mathrm{i}$ albuen, og spritflasker til hånddesinfeksjon fantes i barnehager, skoler, butikker og på arbeidsplasser. I juli 2009 meldte Aftenposten at salget av etanolbasert håndvask hadde eksplodert, apotekene gikk tomme, og enkelte produsenter hadde ventelister ut året (4).

Tidligere studier har vist at god håndhygiene kan redusere forekomsten av luftveisinfeksjoner og tarminfeksjoner (5-8). Effekten synes spesielt stor når intervensjonen rettes mot små barn (6). I en dansk prospektiv, kontrollert undersøkelse med gruppebasert undervisning av personale og barn samt skriftlig informasjon til foreldrene i barnehager ble sykefraværet blant barna redusert med $34 \%$. Det ble i samme undersøkelse funnet signifikant reduksjon i forekomsten av diaré og konjunktivitt (9).

Målet med vår studie var å undersøke om kontaktraten for infeksjonssykdommer på legevakt ble endret mens hygienekampanjen pågikk. Kampanjen var først og fremst rettet mot influensaviruset, men vi har ingen mulighet for å påvise en slik effekt, da vi ikke har noen relevant kontrollgruppe. Vi ønsket derfor å sammenlikne kontaktrater høsten 2009 med et gjennomsnitt av de tre høsthalvårene 2006, 2007 og 2008 for influensa, for andre infeksjonssykdommer man antar at hygienerådene virker på, og en kontrollgruppe med urinveisinfeksjoner.

\section{Materiale og metode}

Materialet består av alle elektroniske legeregningskort som ble levert av legevaktleger fra 1. januar 2006 til 31. desember 2009. De anonymiserte datafilene, som omfattet hele landet, ble levert av Arbeids- og velferdsetaten (NAV) og Helseøkonomiforvaltningen (HELFO). Variablene er kontakttidspunkt (måned), diagnose (ICPC-2-diagnosekoder (International Classification of Primary Care)) og pasientens alder. Alle kontakter er inkludert, både konsultasjoner, sykebesøk, enkle kontakter og telefonkontakter. Papirbaserte refusjonskrav og refusjon som utbetales til pasienten hvis legen ikke har avtale om direkte oppgjør, er ikke inkludert. Det er beregnet at disse utgjorde $4,9 \%$ av alle legevaktkontaktene i 2006 (10).

I tillegg til influensa valgte vi å analysere sju andre infeksjoner som kan ha sammenheng med håndhygiene (tab 1). Som en kontroll inkluderte vi urinveisinfeksjoner, som vi forventet ville være upåvirket av hygienerådene. $\mathrm{Vi}$ registrerte antall kontakter per måned for hver av disse sykdommene og beregnet et månedlig gjennomsnitt for årene 2006-08. Dette gjennomsnittet sammenliknet vi med antall kontakter per måned $\mathrm{i}$ 2009 (fig 2a, e-fig 2b). Siden intervensjonen (hygienekampanjen) kun pågikk andre halvår 2009, gjorde vi en tabellarisk sammenlikning av kontaktrate (per 1000 innbyggere)

\section{Hovedbudskap}

- Høsten 2009 var kontaktraten for influensa ti ganger høyere enn de tre foregående år

- I samme periode var kontaktraten for andre luftveisinfeksjoner og tarminfeksjoner redusert

- Myndighetenes hygienekampanje kan ha bidratt til dette resultatet 
fra 1. juli til 31. desember. Siden den grafiske analysen tydet på store endringer i etterkant av influensaepidemien, valgte vi også å gjøre en tilsvarende tabellarisk analyse bare for desember måned.

Prosjektet ble vurdert av personvernansvarlig i NAV og Personvernombudet for forskning. Siden det ikke er mulig å identifisere enkeltpersoner i materialet, verken direkte eller indirekte, var prosjektet ikke underlagt meldeplikt etter personopplysningsloven.

\section{Resultater}

I 2006 var det i alt 1626644 kontakter til legevakt. Antallet økte gradvis de påfølgende årene, og i 2009 var det 1782761 kontakter. Tabell 1 viser at kontaktraten for influensa var ti ganger høyere høsten 2009 enn de tre foregående årene. Det var betydelig nedgang $\mathrm{i}$ alle de andre infeksjonene, med unntak av akutt øvre luftveisinfeksjon og urinveisinfeksjon. Tabell 2 viser at $i$ desember måned var det også tydelig færre tilfeller av akutt øvre luftveisinfeksjon, mens det var små endringer for urinveisinfeksjoner. Tendensen var den samme i ulike aldersgrupper (data ikke vist).

Figur 2 viser at det var færre kontakter for flere av infeksjonssykdommene gjennom hele året 2009. Kontakt for akutt øvre luftveisinfeksjon økte mer enn vanlig tidlig høsten 2009, samtidig med influensaen, men falt så til under gjennomsnittet på slutten av året, $\mathrm{i}$ etterkant av influensaepidemien.

\section{Diskusjon}

Dette materialet er så godt som fullstendig. Underdekningen var beregnet til mindre enn $5 \%$ i 2006, og er blitt enda mindre senere. Innføringen av automatisk frikort forutsetter at refusjonskrav sendes inn elektronisk. I den grad underdekningen er blitt mindre, vil dette kunne tilsløre en mulig effekt av hygieneintervensjonen, men vi mener disse avvikene er så små at de kan neglisjeres.

Diagnosene på legevakt er som regel basert på anamnese og klinisk undersøkelse alene. I noen grad kan man støtte seg til måling av C-reaktivt protein, urinprøve og hurtigtest for streptokokker, men det er åpenbart at feildiagnoser vil skje. Det er likevel liten grunn til å anta at antall feildiagnoser vil variere vesentlig fra det ene året til det andre, og sammenlikninger på gruppenivå vil derfor likevel kunne være valide.

Den ekstreme oppmerksomheten rundt influensa i 2009 kan imidlertid ha bidratt til systematisk overdiagnostisering av influensa på bekostning av andre, liknende infeksjoner. Vi så likevel at kontaktraten for akutt øvre luftveisinfeksjon til å begynne med økte parallelt med raten for influensa. Svineinfluensaen var i mange tilfeller ganske mild (11), og kan i noen tilfeller ha blitt klassifisert som en vanlig forkjølelse. I etterkant av influensaepidemien var også forekomsten av akutt øvre luftveisinfeksjon betydelig lavere i 2009 enn de foregående årene.
En endret legesøkningsatferd kan tenkes å påvirke den registrerte kontaktraten for sykdom. Man kan tenke seg at personer med mildere sykdom lot være å oppsøke legevakt og i større grad kontaktet fastlegen under influensaepidemien. Det er nesten ni ganger så mange konsultasjoner hos fastlegene som på legevakt (10), så selv mindre endringer i bruk av fastlegen kan medføre store endringer i bruk av legevakt. Vi har ingen relevant informasjon om kontaktratene hos fastlegene, men våre data viser at antall registrerte kontakter på legevakt økte jevnt gjennom hele perioden 2006-09.

Vår hypotese var at vi ville observere færre tilfeller av luftveisinfeksjoner og tarminfeksjoner som følge av hygienetiltakene. $\mathrm{Vi}$ vil imidlertid ikke vente at urinveisinfeksjoner påvirkes av en kampanje for bedre håndhygiene. Dette bekreftes da også $\mathrm{av}$ våre funn. Disse observasjonene er forenlig med en mulig effekt av hygienekampanjen. Det er imidlertid også andre alternative forklaringer.

Siden det var færre infeksjonssykdommer allerede i forste halvår 2009 sammenliknet med de foregående årene, er dette trolig uttrykk for naturlige variasjoner. Det gjelder både pneumoni, halsbetennelse, otitt, tarminfeksjoner og til en viss grad sinusitt. Figur 2 viser imidlertid en tendens i retning av færre kontakter for alle infeksjonssykdommene (unntatt urinveisinfeksjoner) på slutten av året. Dette kan ha sammenheng med at det tar noe tid før hygienetiltak får fullt gjennomslag (12), men kan også skyldes at befolkningen i større grad gjennomførte hygienetiltak og i mindre grad utsatte seg for smitterisiko da influensaen herjet som verst.

Det er også mulig at den lave kontaktraten for infeksjonssykdommer i etterkant av influensaepidemien kan ha sammenheng med biologiske effekter av influensaepidemien, virusinterferens (13). Det er mindre sannsynlig at dette har påvirket bakterielle infeksjoner, selv om virale luftveisinfeksjoner ofte er utgangpunkt for bakterielle infeksjo-

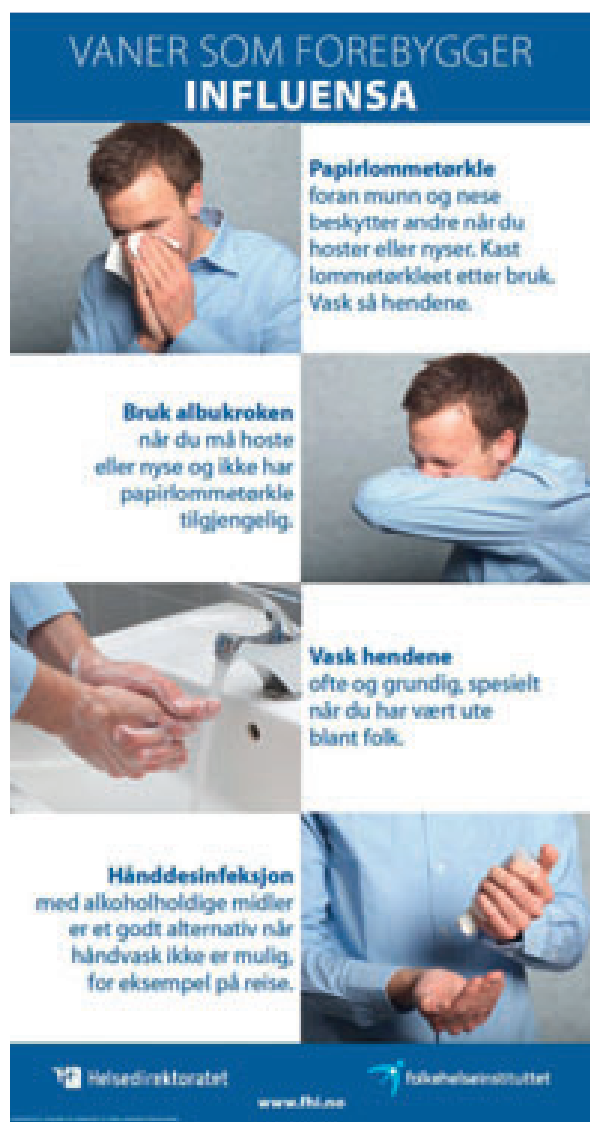

Figur 1 Plakaten «Vaner som forebygger influensa» ble utgitt i juni 2009 og distribuert til landets apotek, legekontorer, kommuneleger, legevakter og helseforetak

ner i luftveiene. Det er vanskelig å skille slike biologiske effekter fra effektene av hygienetiltak. Hygienetiltakene ble imidlertid iverksatt om sommeren, mens influensaviruset først nådde sitt høydepunkt i oktober/november. Når vi ser at nedgangen $i$ antall kontakter for konjunktivitt kom relativt tidlig, er det rimelig å anta at hygienerådene $i$ alle fall har hatt en betydning for denne sykdommen.

Også blant eldre fant vi færre luftveisinfeksjoner og tarminfeksjoner (data ikke

Tabell 1 Kontaktrate på legevakt (per 1000 innbyggere) fra 1. juli til 31. desember 2009 sammenliknet med et gjennomsnitt for tilsvarende perioder 2006 -08, samt ratio $195 \%$ konfidensintervalll mellom kontaktratene

\begin{tabular}{lcccc} 
Diagnoser & $\begin{array}{c}\text { Kontaktrate } \\
\text { ICPC-2- } \\
\text { kode }\end{array}$ & $\begin{array}{c}\text { Kontaktrate } \\
\text { (n= }=4686 \text { 175) }\end{array}$ & $\begin{array}{c}\text { 2009 } \\
\text { (n = 4799 252) }\end{array}$ & $\begin{array}{c}\text { Kontaktrateratio } \\
(95 \% \text { KI) }\end{array}$ \\
\hline Influensa & R80 & 0,83 & 8,46 & $10,25(9,91-10,59)$ \\
\hline Akutt øvre luftveisinfeksjon & R74 & 8,66 & 8,88 & $1,02(1,01-1,04)$ \\
\hline Konjunktivitt & F70 & 3,29 & 2,43 & $0,74(0,72-0,76)$ \\
\hline Otitt & H71 & 2,78 & 2,02 & $0,73(0,71-0,75)$ \\
\hline Sinusitt & R75 & 2,12 & 1,49 & $0,70(0,68-0,72)$ \\
\hline Halsbetennelse & R72, R76 & 3,89 & 3,08 & $0,79(0,78-0,81)$ \\
\hline Pneumoni & R81 & 3,44 & 2,41 & $0,70(0,68-0,72)$ \\
\hline Tarminfeksjon & D70, D73 & 1,76 & 1,45 & $0,82(0,80-0,85)$ \\
\hline Urinveisinfeksjon & U71, U72 & 6,88 & 7,08 & $1,03(1,01-1,04)$
\end{tabular}



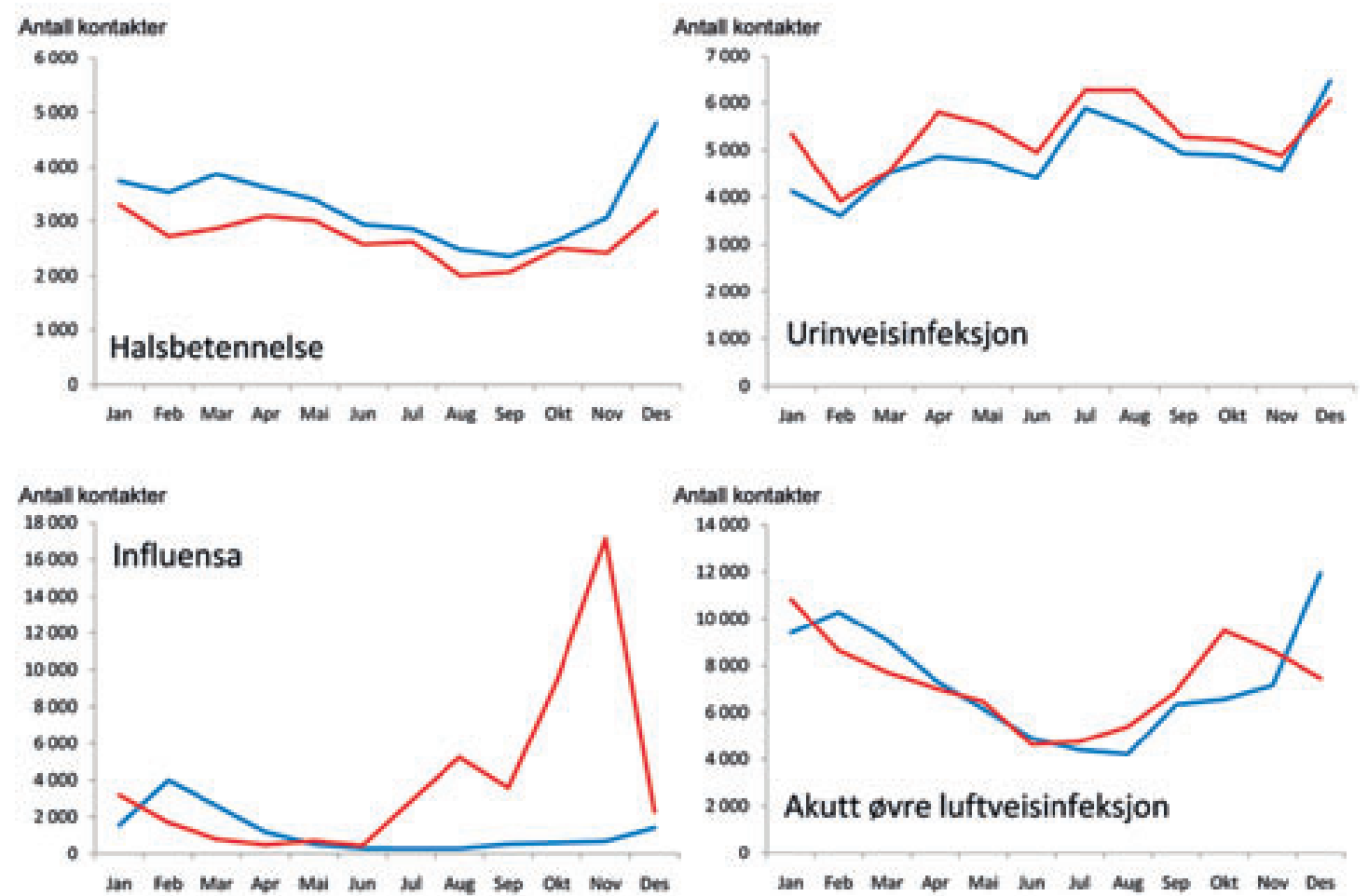

Figur 2a Antall legevaktkontakter per måned for ulike infeksjonssykdommer 2009 (rød) og gjennomsnittet av årene 2006-08 (blå). Ulik skalering. Flere infeksjonssykdommer vises i e-figur $2 b$, som finnes kun i nettutgaven av artikkelen

vist). Eldre ble i liten grad smittet av svineinfluensa, og vi kan derfor anta at biologiske effekter av selve influensaen har spilt en liten rolle i denne aldersgruppen. På den annen side vil også de eldre være utsatt for mindre smittepress fordi det generelt er mindre infeksjonssykdommer i befolkningen.

\section{Konklusjon}

Det var en nedgang i kontaktraten for luftveisinfeksjoner og tarminfeksjoner på slutten av 2009. Våre data er forenlige med at dette var en effekt av hygienekampanjen, men andre faktorer kan også ha bidratt til dette resultatet.

Oppgitte interessekonflikter: Ingen

E-figur $2 b$ finnes kun i Tidsskriftets nettutgave

\section{Litteratur}

1. Hauge SH, Dudman SG, Borgen Ket al. Sykdom forårsaket av nytt A(H1N1)-influensavirus. Tidsskr Nor Legeforen 2009; 129: 1736-9.

2. Haug C. Panikkpandemi? Tidsskr Nor Legeforen 2009; 129: 979.

3. Press K, Hansen EH, Hunskår S. Influensapandemien høsten 2009: Henvendelser til legevakt.

Tabell 2 Kontaktrate på legevakt (per 1000 innbyggere) i desember 2009 sammenliknet med gjennomsnitt for desember 2006-08, samt ratio (95\% konfidensintervall) mellom kontaktratene

\begin{tabular}{lcccc} 
Diagnoser & $\begin{array}{c}\text { ICPC-2- } \\
\text { kode }\end{array}$ & $\begin{array}{c}\text { Kontaktrate } \\
2006-08 \\
(\mathrm{n}=4686 \text { 175) }\end{array}$ & $\begin{array}{c}\text { Kontaktrate } \\
\text { (n= }=4799252)\end{array}$ & $\begin{array}{c}\text { Kontaktrateratio } \\
(95 \% \mathrm{KI})\end{array}$ \\
\hline Influensa & $\mathrm{R} 80$ & 0,30 & 0,48 & $1,59(1,48-1,69)$ \\
\hline Akutt øvre luftveisinfeksjon & $\mathrm{R} 74$ & 2,53 & 1,55 & $0,61(0,60-0,63)$ \\
\hline Konjunktivitt & $\mathrm{F} 70$ & 0,77 & 0,57 & $0,74(0,70-0,77)$ \\
\hline Otitt & $\mathrm{H} 71$ & 0,72 & 0,44 & $0,61(0,58-0,64)$ \\
\hline Sinusitt & $\mathrm{R} 75$ & 0,60 & 0,35 & $0,58(0,55-0,62)$ \\
\hline Halsbetennelse & $\mathrm{R} 72, \mathrm{R} 76$ & 1,00 & 0,66 & $0,66(0,63-0,69)$ \\
\hline Pneumoni & $\mathrm{R} 81$ & 0,97 & 0,45 & $0,47(0,45-0,49)$ \\
\hline Tarminfeksjon & $\mathrm{D} 70, \mathrm{D} 73$ & 0,44 & 0,29 & $0,66(0,61-0,70)$ \\
\hline Urinveisinfeksjon & U71, U72 & 1,38 & 1,26 & $0,92(0,88-0,95)$
\end{tabular}

Rapport nr. 3-2010. Bergen: Nasjonalt kompetansesenter for legevaktmedisin, Uni helse, 2010

4. Salvesen G, Gerhardsen W, Løyning A et al Salget har $\varnothing \mathrm{kt}$ med 554 prosent. Aftenposten 27. juli 2009. www.aftenposten.no/nyheter/iriks/ article3189069.ece (10.2.2011).

5. Jefferson T, Del Mar C, Dooley L et al. Physical interventions to interrupt or reduce the spread of respiratory viruses. Cochrane Database Syst Rev 2010; nr.1: CD006207.

6. Jefferson T, Del Mar C, Dooley L et al. Physical interventions to interrupt or reduce the spread of respiratory viruses: systematic review. BMJ 2009; 339: b3675

7. Ejemot RI, Ehiri JE, Meremikwu MM et al. Hand washing for preventing diarrhoea. Cochrane Database Syst Rev 2008; nr. 1: CD004265.

8. Aiello AE, Coulborn RM, Perez V et al. Effect of hand hygiene on infectious disease risk in the community setting: a meta-analysis. Am J Public Health 2008; 98: 1372-81.

9. Ladegaard MB, Stage V. Håndhygiejne og småbørnssygelighed i daginstitutioner. En interventionsundersøgelse. Ugeskr Læger 1999; 161: 4396-400.

10. Nossen JP. Hva foregår på legekontorene? Konsultasjonsstatistikk for 2006. NAV-rapport nr. 4/ 2007. Oslo: Arbeids- og velferdsdirektoratet, 2007.

11. Ulvestad E, Swensen E, Simonsen GS et al. Pandemien - bidrag til etterpåklokskap. Tidsskr Nor Legeforen 2010: 130: 169-71.

12. Luby SP, Agboatwalla M, Hoekstra RM et al. Delayed effectiveness of home-based interventions in reducing childhood diarrhea, Karachi, Pakistan. Am J Trop Med Hyg 2004: 71: 420 - 7.

13. Anestad G, Nordbø SA. Hemmet rhinovirus influensa A(H1N1)-pandemien? Tidsskr Nor Legeforen 2010; 130: 1932-4.

Mottatt 19.12. 2010, første revisjon innsendt 16.1 . 2011, godkjent 10.2. 2011. Medisinsk redaktør Lars Frich. 